\title{
MODELAMENTO DA BACIA DO PARANÁ - RESERVATÓRIO CAPIVARA - ATRAVÉS DA INVERSÃO CONJUNTA DE FUNÇÃO DO RECEPTOR E DE SONDAGEM MAGNETOTELÚRICA
}

\author{
Manuel Ivan Zevallos Abarca \\ Orientador: Dr. Marcelo Sousa de Assumpção (IAG-USP) \\ 101 p. - Tese (Doutorado) - Defesa 06.10.2004
}

RESUMO. As metodologias de Função do Receptor e sondagem Magnetotelúrica foram aplicadas na bacia do Paraná com fins de imageamento das camadas de rochas sedimentares e vulcânicas que preenchem a bacia. A função do receptor precisa ser adaptada para esse fim, pois a resposta a estruturas finas e rasas requer sinal sísmico com conteúdo de altas frequeências. Função do Receptor de alta frequêencia (até $\sim 10 \mathrm{~Hz}$ ) pode ser usada para definir camadas mais finas que $1 \mathrm{~km}$. 0 uso conjunto de sondagens MT contribui para diminuir a não unicidade das inversões de função do receptor. Foi implementado um Algoritmo Genético para fazer a inversão simultânea de ambos tipos de dados. Os resultados das inversões em três estações sísmicas e suas correspondentes sondagens magnetotelúricas mostram dois modelos sismo-elétricos que nomearemos Sul e Norte. 0 modelo Sul tem a camada de basaltos até $1 \mathrm{~km}$ de profundidade, identificada pelas altas velocidades sísmicas e alta resistividade. Sob essa camada há diminuição de velocidade e de resistividade, identificando os sedimentos, em duas camadas, embaixo das quais encontramos 0 embasamento aproximadamente a 3, $5 \mathrm{~km}$ de profundidade. 0 modelo Norte tem menor espessura dos basaltos, $\sim 0,6 \mathrm{~km}$. A profundidade do embasamento estaria por volta dos $4,3 \mathrm{~km}$, ou alternativamente na mesma profundidade $\sim 3,6 \mathrm{~km}$, com uma segunda zona de inversão de velocidades no fundo da bacia.

ABSTRACT. Receiver Function and Magnetoteluric methods were applied in the Paraná basin to image sedimentary and volcanic rock layers. Receiver function had to be adapted to reveal thin and shallow layers, using high frequency (up to $10 \mathrm{~Hz}$ ) P-waves from subduction zone earthquakes. A Genetic Algorithm was developed to perform a joint inversion of both methods. MT soundings contributes to reduce ambiguities of receiver function inversions. Results of inversions in three seismic stations shows two different seismo-electric models for the basin, called South and North models. In the South model the upper layer is a $1 \mathrm{~km}$ thick basalt layer with high velocity and high resistivity. Below the basalt a low velocity and low resistivity zone is interpreted as sedimentary rocks, with two main layers. We found the basementt rocks with typical high resistivity and high velocity at $3.5 \mathrm{~km}$ depth. The North model is slightly different, the basalts are $0.6 \mathrm{~km}$ thick and basement depth reaches $4.3 \mathrm{~km}$. Alternatively, the basement depth could be the same $(\sim 3.6 \mathrm{~km})$ with a second low velocity zone at the bottom of the basin. 